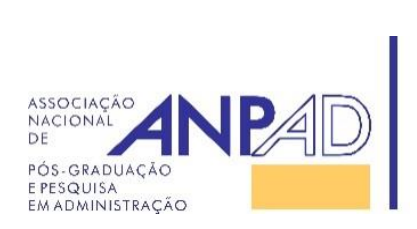

Disponível em

http://www.anpad.org.br/rac

RAC, Rio de Janeiro, v. 21, n. 4, art. 5,

pp. 524-544, Julho/Agosto, 2017

http://dx.doi.org/10.1590/1982-7849rac2017160199

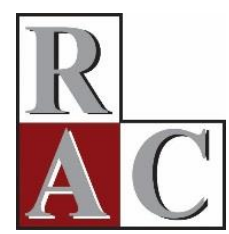

$(\mathrm{cc})$ EY

\title{
Disputas do Estado em Favelas: O Campo Burocrático e o Capital Espacial
}

Capital Dynamics in Favelas (Brazilian Slums): The Bureaucratic Field and the Spatial Capital 


\title{
Resumo
}

Neste artigo nos propomos a analisar como se dão as disputas por capitais pelos agentes do campo burocrático do Estado em ação nas favelas, no contexto da pacificação. Para tal, pautamo-nos na perspectiva teórica de Pierre Bourdieu e realizamos uma pesquisa de campo de inspiração etnográfica em duas favelas cariocas, que contou com observação participante e 91 entrevistas semiestruturadas. Pode-se concluir que as espécies de capital mais valorizadas no campo burocrático do Estado em ação nas favelas são o capital econômico, uma espécie fundamental, e o capital espacial, uma espécie específica encontrada no campo em questão, que diz respeito à ocupação do território ou apresentação de resultados materiais. Portanto, os agentes que acumulam um maior volume destes capitais, como a Unidade de Polícia Pacificadora (UPP) e o Programa de Aceleração do Crescimento (PAC), parecem se aproximar mais das posições de dominantes do campo.

Palavras-chave: campo burocrático do Estado; capital; favelas.

\begin{abstract}
In this article we aim to analyze the disputes over capital by bureaucratic State agents acting in favelas within the context of pacification. To this end, we rely on the theoretical perspective of Pierre Bourdieu and we conducted an ethnography-inspired field research in two Rio de Janeiro favelas, which included participant observation and 91 semi-structured interviews. We concluded that the types of capital most valued by the State bureaucratic agents acting in the favelas are economic capital, a fundamental type, and spatial capital, a specific type found in the field in question related to occupation of territory or material results. Therefore, agents that accumulate a larger volume of these capitals, such as the UPP (Police Pacification Unit) and the PAC (Program for Growth Acceleration), seem to achieve dominant field positions.
\end{abstract}

Key words: State bureaucracy; capital; favelas (slums). 


\section{Introdução}

Era uma noite de quarta-feira, quando a primeira autora deste artigo adentrou o teatro localizado em uma favela da Zona Sul. A visita à favela fazia parte da pesquisa de campo que vínhamos desenvolvendo, e naquele dia a ida a campo foi motivada por um evento específico: uma audiência pública convocada com o propósito de discutir problemas da comunidade. Representantes dos mais diversos órgãos públicos mostraram-se presentes. A maioria dos rostos ansiosos em cima do palco já eram familiares da rotina na favela e pertenciam a pessoas que trabalhavam ali. Contrariando nosso pressuposto inicial de que em favelas não há Estado, àquela altura já não era mais possível negar que o Estado estava presente nas favelas, de forma concreta e objetiva, representado pelas figuras daquelas pessoas que se acomodavam no palco.

Um olhar retrospectivo para os meses de pesquisa de campo que já haviam ficado para trás nos fez notar que foi aquela a ocasião em que mais nos aproximamos do encontro de uma entidade, grupo ou organização que poderíamos denominar de Estado: o grupo de pessoas em cima do palco. Pela primeira vez em campo, a pesquisadora pôde respirar aliviada, direcionar o seu olhar para um único lugar e dizer, com certa tranquilidade, que estava observando o Estado na favela. Quase todos estavam ali.

Entretanto, este foi um momento atípico. Desde que iniciamos nossa pesquisa nas favelas, com o objetivo de acompanhar as ações do Estado, vivemos uma angústia constante. O Estado estava em muitos lugares ao mesmo tempo. E o olhar da pesquisadora, único, não dava conta de observá-lo como um todo. A agonia de ter que escolher para onde olhar acompanhou a trajetória em campo e resultou em uma agenda complexa, em minutos contados, em difíceis decisões entre um evento e outro, e em uma pesquisa de campo muito maior do que pudemos antecipar. Mas, acima de tudo, resultou em uma frustração: a impossibilidade de encontrar uma unidade que pudéssemos chamar de Estado.

Em nosso esforço de acompanhar cada uma delas, em separado ou em parcerias, vimos que para além de uma discordância em termos de horários e locais de atuação, as pessoas que se apresentavam na favela como representantes do Estado discordavam em muitos outros aspectos. Críticas diretas ou indiretas, disputas por recursos em geral, omissão de informações e conflitos abertos ou velados contrapunham-se a ações conjuntas, compartilhamentos de recursos, de ideias ou de angústias, e até relações de amizades. As relações que observávamos em campo nos apontavam para o fato de que a entidade que viemos observar consistia, na verdade, em uma rede de relações entre posições: o Estado era melhor descrito enquanto um campo de poder.

Como em todo campo, era claro que o grau de legitimidade dos agentes não era homogêneo. Pautando-nos na ideia de Bourdieu (2011) de que é a partir da análise da acumulação de capital, isto é, do volume de capital angariado por cada agente, que podemos compreender as posições dos agentes no campo, passamos a nos atentar aos recursos acumulados pelos agentes, bem como às diferenças de valorização de tais recursos. Seguindo esta lógica, neste artigo nos propusemos a responder à seguinte questão: como se dão as disputas por capitais pelos agentes do campo burocrático do Estado em ação nas favelas, no contexto da pacificação ${ }^{(1)}$ ?

\section{Os Campos de Poder e a Dinâmica de Capitais}

O conceito de campo é definido por Bourdieu e Wacquant (2012, p. 134) "como una red o una configuración de relaciones objetivas entre posiciones". Os campos, assim pensados, são relacionais, dinâmicos, em constante mudança (Everett, 2002). Para Bourdieu e Wacquant (2012), é importante ter em mente que cada campo possui sua lógica específica que vai determinar o seu funcionamento particular. Marca-se, assim, que o campo deve ser pensado "como um espaço estruturado com suas próprias regras de funcionamento e suas próprias relações de força" (Misoczky, 2006, p. 81). 
Como estão associados à ideia de poder ou de dominação (Everett, 2002), os campos são constantemente comparados aos jogos. Seguindo sua analogia com um jogo, Bourdieu e Wacquant (2012) comparam os diferentes tipos de capital como cartas de um baralho, sendo que o valor relativo de cada uma delas muda de acordo com o jogo em questão. Os capitais servem, portanto, como armas na luta por ascendência em um campo (Emirbayer \& Johnson, 2008).

Entretanto, não são os tipos de capitais que diferenciam um campo de outro, mas a sua lógica inerente de disputa e dominação, que, eventualmente, pode levar ao recurso de capitais específicos. Existem espécies de capitais que são consideradas fundamentais, e que, portanto, fazem-se presentes em vários campos, como o capital econômico, social ou cultural (Sallaz \& Zavisca, 2007). Mas existem, ainda, espécies especializadas de capital que só têm valor dentro de um campo particular, como é o caso do capital científico, identificado por Bourdieu (2004) como o capital específico do campo científico. Todas as formas de capital estão conectadas, podendo ser convertidas umas nas outras (Everett, 2002).

Merece relevo na perspectiva de Bourdieu uma forma destacada de capital, que o autor denomina de capital simbólico, ou seja, "a forma percebida e reconhecida como legítima das diferentes espécies de capital” (Bourdieu, 2012, p. 135).

Nesta luta dinâmica pelos recursos no campo, destacam-se as figuras dos agentes, que compõem a estrutura do campo. Quando um determinado agente possui uma ou mais espécies de capital que são eficazes naquele campo, ele adquire poder e influência, e isso o faz existir como um agente no campo em questão (Bourdieu \& Wacquant, 2012). A distribuição dos agentes no campo, por sua vez, dependerá do volume e da estrutura de capital que possuem (Bourdieu, 1996).

Com base em Bourdieu, e com vistas a marcar as diferentes posições assumidas pelos atores nos campos, Fligstein e McAdam (2012) adotam os termos incumbentes e desafiadores. Enquanto os primeiros assumem posições privilegiadas e uma influência desproporcional nos campos, os segundos assumem posições menos favorecidas e têm pouca influência no campo.

\section{Sobre o Estado enquanto Campo de Poder}

O Estado, na visão particular de Bourdieu (2012), é entendido como um campo burocrático ou campo da função pública, que se define "par la possession du monopole de la violence symbolique et légitime", capaz de regular os demais campos (Bourdieu, 2012, p. 14). Em termos mais específicos, Bourdieu, Wacquant e Farage (1994, p. 3), a partir da proposição weberiana, definem o Estado como "an X (to be determined) which sucessfully claims the monopoly of the legitimate use of physical and symbolic violence over a definite territory and over the totality of the corresponding population".

Assim como os demais campos descritos por Bourdieu, o campo burocrático do Estado também possui uma lógica própria. Segundo Bourdieu (2014), no interior deste campo joga-se um jogo particular, guiado por uma lógica burocrática. Dentro deste campo, a política está posta em jogo, e os agentes que possuem o privilégio de entrar neste jogo também adquirem o privilégio de ter acesso a um recurso particular, que Bourdieu (2014) denomina de um recurso universal ou metacapital, por meio do qual tais agentes tornam-se aptos a falar em nome da totalidade de um grupo, do universum, em nome de um bem público, a falar o que é bom para o público. Dito de outra forma, no interior do campo burocrático, os agentes lutam pela posse de um capital capaz de lhes dar poder sobre os outros campos.

Mais uma vez indo ao encontro de Bourdieu, pode-se dizer que Fligstein e McAdam (2012) também enxergam nesta perspectiva o benefício de evitar o problema de reificar o Estado que, para eles, definitivamente, não é um ator unificado. E, portanto, a combinação de ambas as teorias tornou-se elucidativa para a análise do campo do Estado aqui empreendida e apresentada a seguir. 


\section{Método}

Para o desenvolvimento desta pesquisa, foi realizada uma pesquisa de campo com duração de um ano e quatro meses (de janeiro de 2013 a abril de 2014) em duas favelas cariocas. A pesquisa de campo incluiu observação participante, de inspiração etnográfica, bem como 91 entrevistas semiestruturadas.

Na pesquisa de campo desenvolvida no presente estudo, a primeira autora deste artigo buscou, em um primeiro momento, inserir-se na vida das favelas estudadas por meio de contato com os moradores locais, e a partir deles identificar os representantes do Estado que se inserem no cotidiano das favelas. Vale ressaltar que, especialmente na favela da Zona Sul, onde o tráfico de drogas ainda possui muito poder no território, foi preciso dialogar com moradores próximos aos meninos do tráfico, para se certificar de que a primeira autora possuía autorização para realização da pesquisa e para frequentar a UPP local. Nas visitas às favelas eram sempre realizadas notas de campo. No que concerne às reuniões entre representantes do Estado e moradores, acompanhadas em nossa pesquisa de campo, 6 delas foram gravadas e transcritas, mediante autorização prévia.

Também foram realizadas entrevistas com representantes do Estado que atuavam nas favelas e com moradores, para aprofundarmos algumas informações. Nesse sentido, foram realizadas 91 entrevistas, com a duração, em média, de 2 horas cada uma. Para a determinação do número de entrevistas usamos o critério de saturação. Ou seja, consideramos que havíamos alcançado um número suficiente de entrevistados quando informações e categorias novas pararam de surgir nos dados coletados. Vale ressaltar que as entrevistas seguiram um roteiro semiestruturado. Os entrevistados são especificados nas Tabelas 1, 2 e 3 a seguir:

Tabela 1

\section{Entrevistados na Favela da Zona Sul}

\begin{tabular}{ll}
\hline Categoria de Entrevistado & Quantidade \\
\hline Morador & 18 \\
Representantes da UPP & 10 \\
Representantes do PAC & 5 \\
Representantes da UPP Social & 2 \\
Representantes do Territórios da Paz & 2 \\
Representantes do CRAS & 2 \\
Representantes da Clínica da Família & 1 \\
Representantes do CIEP & 1 \\
Representantes da Comlurb & 2 \\
Representantes do ITERJ & 4 \\
\hline Total & $\mathbf{4 7}$ \\
\hline
\end{tabular}


Tabela 2

\section{Entrevistados na Favela da Zona Norte}

\begin{tabular}{ll}
\hline Categoria de Entrevistado & Quantidade \\
\hline Morador & 14 \\
Representante da UPP & 11 \\
Representante da UPP Social & 2 \\
Representante do Territórios da Paz & 2 \\
Representante do CRAS & 6 \\
Representante da Comlurb & 2 \\
\hline Total & $\mathbf{3 7}$ \\
\hline
\end{tabular}

Tabela 3

\section{Entrevistados Gerais}

\begin{tabular}{ll}
\hline Categoria de Entrevistado & Quantidade \\
\hline Representante da UPP & 2 \\
Representante da UPP Social & 3 \\
Representante do Territórios da Paz & 2 \\
\hline Total & 7 \\
\hline
\end{tabular}

Os moradores entrevistados foram selecionados com base na observação participante, que possibilitou identificar lideranças comunitárias e moradores que tinham mais contato com os representantes do Estado que atuavam nas favelas investigadas. Os representantes do Estado entrevistados também foram selecionados com base na observação, que possibilitou identificar aqueles que atuavam diretamente na favela em questão ou ocupavam um cargo superior nos programas voltados para a favela, participando ativamente das disputas no campo.

As entrevistas transcritas, as notas de campo e as reuniões gravadas e transcritas totalizaram 3.200 páginas de dados. A análise dos dados foi realizada com o auxílio do software Atlas.ti 7 , de forma a facilitar a organização dos dados. Com a ajuda do software, a primeira etapa da análise se deu por meio de um processo de codificação manual dos temas emergentes, baseados no interesse de pesquisa inicial. Por meio deste processo, que consistiu em uma análise detalhada, linha por linha, todos os dados foram codificados, resultando em categorias emergentes, que aqui serão denominadas de categorias empíricas.

No estágio seguinte, as categorias empíricas foram agregadas em categorias de segunda ordem, de acordo com padrões comuns entre elas. Em uma terceira etapa da análise de dados, por meio da integração com a teoria, buscou-se a emergência de temas teóricos para o desenvolvimento de categorias teóricas.

\section{A Dinâmica dos Capitais: Marcando Posições}

Voltando à audiência pública com a qual abrimos este artigo, foi também ali, quando pela primeira vez, quase todos os agentes do campo apareceram juntos em um mesmo lugar, que pudemos perceber de forma mais clara uma diferença na legitimidade dos agentes. Embora aquele fosse um evento neutro, que não levava o nome de nenhum dos agentes, a figura pública que o organizava não hesitou em 
destacar a Unidade de Polícia Pacificadora (UPP) como um ator que "ajudou muito a tornar esse, essa reunião, em realidade" (Audiência Pública gravada, 19 junho de 2013), e como tal ocupava um lugar central em cima do palco. Um representante do Programa de Aceleração do Crescimento (PAC) ${ }^{(2)}$ também foi chamado ao palco e anunciado como uma figura que todos ali conheciam bem. A gestora da UPP Social ${ }^{(3)}$ foi chamada ao palco em improviso, mas permaneceu calada durante toda a audiência, sentada em um canto do palco, quase esquecida. Já o Territórios da $\mathrm{Paz}^{(4)}$ não foi mencionado em nenhum momento, e também não subiu ao palco - assistia à audiência da plateia, junto aos moradores.

Percebemos que existia uma diferença no grau de legitimidade dos agentes que podia ser explicada pelas dinâmicas de capitais. Pautando-nos nesta ideia, passamos a nos atentar aos recursos disputados pelos agentes, bem como às diferenças de valorização de tais recursos.

\section{O capital social}

Depois de muitos chopes no bar e cafés em casas da favela, que envolviam momentos informais de socialização entre representantes do Estado e moradores, àquela altura já estava claro que agentes do Estado também estabeleciam laços de amizade e outras relações pessoais com os moradores da favela. $\mathrm{E}$ as frequentes crises de ciúmes envolvendo, principalmente, representantes do Territórios da Paz e da UPP Social, apontavam-nos para uma disputa destas relações.

Bourdieu (2012) refere-se ao capital social como sinônimo de uma força social que possibilita que os agentes entrem nas lutas pelo monopólio de poder. Como um capital de relações (Bourdieu, 2014), corresponde, de forma mais direta, ao conjunto de acessos sociais, que se dão sob a forma de relacionamento e redes de contatos (Thiry-Cherques, 2006). O capital social, assim definido, estava em disputa no campo do Estado que observávamos na favela.

Os agentes da UPP declaram abertamente o seu interesse em realizar estratégias para se aproximar da comunidade. Os policiais de ambas as favelas apontavam como as suas principais relações a associação de moradores e os idosos das comunidades, que os recebiam muito bem. As relações de verdadeira amizade eram pontuais, e muitas vezes estavam relacionadas com o papel social assumido pelo policial.

É perceptível entre os moradores um certo temor em relação à UPP, e um afastamento forçado. Depois de um longo histórico de relações mais do que conturbadas entre moradores e policiais, as relações passadas entre polícia e favela ainda assombram os moradores, e a histórica falta de confiança no Estado também faz crer que as UPPs não vão durar para sempre e que o poder do tráfico voltará pronto para punir aqueles que as tiverem apoiado. Esta é uma narrativa frequente entre os moradores, que com medo de possíveis retaliações, preferem se manter afastados. De acordo com uma moradora:

"Ninguém quer contato com eles. Porque também tem aquele lado de ser reprimido pelo outro lado, né? Porque quem fica de muito papo com a polícia sabe que a pessoa vai achar, 'ah, tá dando, quem mora no morro, não sei o quê'. Vai chamar de X-9, ninguém quer o contato com a polícia porque sabe que polícia não presta". (Morador 18, Favela da Zona Sul).

Acontece que o temor não era uma mera paranoia. $\mathrm{O}$ tráfico, ainda presente nas favelas, tinha as suas formas de retaliação, mesmo com a presença da UPP. Com o tempo a pesquisadora começou a ouvir relatos de moradoras que foram expulsas do morro por traficantes porque mantinham relações amorosas com policiais. Ouvia-se casos de moradores punidos por conversarem com policiais, ou comerciantes que recebiam os policiais e que foram proibidos de assim fazê-lo. As retaliações àqueles que estabeleciam relações com os representantes das UPPs eram conhecidas e faziam surtir o efeito desejado: um afastamento entre a comunidade e os policiais.

Em casos mais extremos, que também eram frequentes, os moradores praticavam atos de agressão aos representantes da UPP local, estimulados por conflitos decorrentes de abordagens policiais, tentativas de prisões, interrupções de festas. Para além de um bom dia não dito, as pedradas deixavam 
clara a insatisfação de alguns moradores com a presença da UPP. Em termos de capital social, a UPP não saía na frente.

O PAC, que se encontrava em sua segunda fase, também era assombrado por um passado ruim. Moradores e agentes do programa se lembravam dos problemas da primeira fase: obras não concluídas, cronograma não cumprido, atrasos no aluguel social - tudo contribuía para uma falta de confiança dos moradores no PAC. Para se livrar das sombras do passado, os agentes cuidavam de sua postura e tentavam recuperar a confiança.

Sem interferência do tráfico nesta relação, os moradores frequentavam as reuniões do PAC, que em geral eram bem cheias e agitadas, e iam ao chamado canteiro social, onde a equipe da frente social do PAC realizava plantões para atendimentos aos moradores. Mas as relações não passavam disso: eram, em geral, formais. A lógica do PAC de impor obras prontas e o tratamento infantilizado que às vezes dava aos moradores em reuniões fazia com que as relações fossem às vezes conflituosas.

Os motivos por trás da mútua agressividade, que pudemos presenciar em muitas reuniões, diziam respeito a atrasos nas obras e à revolta dos moradores em ter que deixar suas casas para viver de aluguel social enquanto os apartamentos estivessem prontos. Mas eram nas negociações que antecediam as remoções que os conflitos se tornavam mais intensos. Pressões e ameaças aos moradores para que estes deixassem suas casas eram sempre relatadas. E os agentes do PAC, por sua vez, descreviam a agressividade da parte dos moradores nos processos de negociação. As relações eram longe de harmoniosas, e quando mais tranquilas, não passavam de uma relação formal.

Para um programa como a UPP Social, que tem como propósito o encaminhamento de demandas, o acesso à comunidade é de extrema importância e o estabelecimento de boas relações, um meio necessário para o sucesso do trabalho. Para tal, a primeira barreira a ser transposta era o nome do programa, que denunciava uma suposta associação entre a UPP Social e a polícia.

Com a entrada dos agentes em campo, começaram os questionamentos a respeito do nome. Os moradores queriam esclarecimentos a respeito da suposta relação da UPP Social com a polícia, para garantir sua segurança. Os agentes da UPP Social rapidamente se deram conta dos problemas que o nome os trazia e fizeram um esforço para deixar claro que, além do nome, não tinham nenhuma relação com a polícia. Passaram a se identificar como representantes da prefeitura, Instituto Pereira Passos (IPP) ou ONU Habitat, evitando ao máximo o nome UPP Social. Não usavam nenhum tipo de identificação que revelasse o nome oficial do programa.

Mas com o tempo o programa foi se consolidando em campo e, desfeitos os primeiros malentendidos, a relação com os moradores começou a melhorar. Participavam ativamente das reuniões comunitárias, e por diversas vezes foi possível presenciar os moradores recorrendo a eles com demandas ou pedidos de ajuda.

Com a conquista da confiança dos moradores, os agentes da UPP Social passaram a tomar um novo cuidado: não tornar as suas relações em campo muito pessoais. Procuravam sempre se posicionar enquanto prefeitura e marcar sua posição institucional. Criticavam os agentes do Territórios da Paz em sua postura de identificação com os moradores, uma proximidade muito maior, que faz com que os moradores confundam seu papel de representantes do Estado com um papel de morador da favela: "eles se posicionam em coisas muito, quase como sociedade civil, assim" (Representante da UPP Social 4, Favela da Zona Sul).

A visão da UPP Social a respeito do Territórios da Paz não nos pareceu ser sem fundamento. Era inegável a capilaridade que o programa Territórios da Paz tinha na favela, e os fortes vínculos que eles conseguiam estabelecer com os moradores. Para além de sua grande inserção nas comunidades, os agentes do Territórios da Paz, em ambas as favelas, criavam claros laços de amizade com alguns moradores. Com uma compreensão mais clara das relações sociais nas favelas, que em geral são complexas e marcadas por grupos em conflitos, os agentes do Territórios da Paz, em ambas as favelas, surpreendiam-nos com a destreza com que lidavam com os moradores. Observando-os aprendemos muito sobre as relações sociais nas favelas.

RAC, Rio de Janeiro, v. 21, n. 4, art. 5, pp. 524-544, Julho/Agosto, 2017, www.anpad.org.br/rac (cc) 
Mas foi também observando-os que compreendemos que o capital social tem dois lados: se por um lado os acessos sociais ajudam na legitimidade dos agentes, o estabelecimento de relações tão próximas acaba por proporcionar um acúmulo de capital social para o próprio indivíduo em sua esfera pessoal, e não mais para a instituição que ele representa. Em entrevistas com moradores bastante próximos dos agentes do Territórios da Paz, percebemos que estes não mencionavam o programa como um representante do Estado na favela, e quando faziam menção a algum contato com o programa, referiam-se ao nome da pessoa com a qual estabeleciam suas relações.

Os agentes do Centro de Referência de Assistência Social (CRAS) ${ }^{(5)}$ parecem reconhecer a ambiguidade do capital social. Em sua proximidade com os moradores, reclamam de uma percepção de que os moradores às vezes esquecem que os agentes estão ali como representantes do Estado: eles chamam as funcionárias de tia, levam a eles problemas pessoais que vão muito além do seu papel institucional. Os agentes referem-se a essas relações como relações domésticas ou de vizinhança.

Às relações estreitas que possuem com a comunidade, os agentes atribuem um lado positivo, porque os aproxima e gera confiança, mas também reconhecem o seu lado negativo: os papeis se confundem - não se sabe se são Estado ou se são moradores. Reforçam que precisam estar o tempo todo lembrando aos moradores quem eles são ali.

A forma como a partir de elementos empíricos chegamos à categoria teórica de capital social é ilustrada na Figura 1 a seguir:

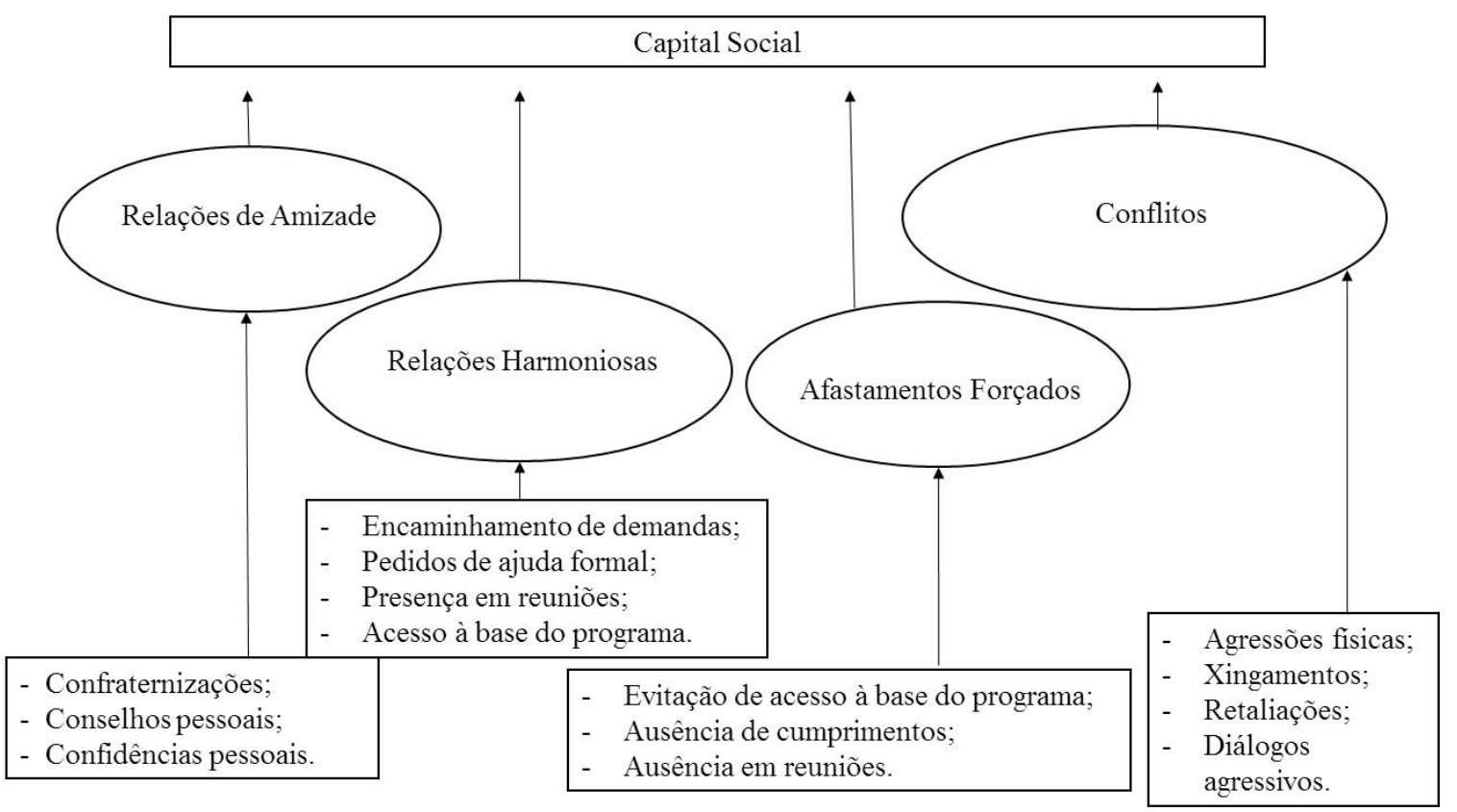

Figura 1. Capital Social

Conforme anteriormente explicitado, o capital social se apresentou nas formas principais de relações de conflito, relações de afastamento, relações harmoniosas, estas mais neutras, e relações de amizade, com laços mais estreitos. As quatro formas principais aparecem em combinações diferentes e não são exclusivas.

\section{O capital informacional}

Foi em fevereiro de 2013, quando a primeira autora estava um pouco mais de um mês em campo, que foi possível assistir à primeira reunião entre UPP e moradores. A sala no interior do prédio da UPP era ocupada por poucos moradores, sendo alguns já conhecidos da pesquisadora. O comandante chegou um pouco atrasado e foi logo se dirigindo à frente da sala. Deu boa noite e se apresentou, para os que ainda não o conheciam, como o novo comandante da UPP daquela comunidade. A comunidade à qual 
o comandante se referia era apenas uma das duas comunidades que ocupavam aquele morro, e a reação dos moradores à sua fala foi imediata: gritavam que aquela era a UPP da outra comunidade também. $\mathrm{O}$ comandante ficou constrangido diante da gafe. Pediu desculpas e, depois de se recuperar do constrangimento, deu prosseguimento à reunião.

Embora nós tivéssemos, na ocasião, pouco tempo de trabalho de campo, já tínhamos conhecimento a respeito das disputas acirradas entre as duas comunidades que dividiam o morro. Historicamente, as duas comunidades não tinham uma boa relação, e moradores de uma das comunidades evitavam ir ao território da outra. Apreendemos esta informação por meio do convívio com os moradores e logo a identificamos como uma questão delicada, com a qual era preciso ter cuidado para não criar desavenças em campo. O comandante da UPP ainda não tinha aquela informação, e ocorridos como este começaram a nos sinalizar para uma interdependência entre o capital social e o acúmulo de informações a respeito da favela pelos agentes.

Ao tratar do campo do Estado, Bourdieu et al. (1994) referem-se à acumulação, neste campo, de um capital informacional. Explicam que esta espécie de capital dá ao Estado a vantagem de pensar a sociedade em sua totalidade, e pode ser acumulada por meio de censos, de estatísticas, de contabilidade nacional, de objetivação, cartografia, arquivos ou codificações, que lhe dão condições de concentrar uma variedade de informações a respeito do território que domina.

Percebemos, nos agentes do campo, um esforço para a concentração de informações sobre a favela, cada um à sua maneira. Para os agentes da UPP, o mais importante era o acúmulo de informações a respeito do tráfico e dos crimes em geral. Reconheciam que, para ter acesso a este tipo de informação, precisavam do auxílio dos moradores, que realizam denúncias constantes à UPP, contando com a garantia de sigilo. Organizando e analisando com cuidado todas as informações, os policiais tinham um conhecimento bastante profundo a respeito dos crimes na favela, e sabiam quem eram os traficantes: "a gente sabe quem são os principais chefes do tráfico, que ficam ali tomando cerveja aqui nessa birosca aí do lado aí o dia inteiro" (Representante da UPP 3, Favela da Zona Sul).

Embora os policias reconheçam que para obter informações, ou acumular o capital informacional, precisam manter boas relações com a comunidade, ou ter capital social, eles parecem não perceber a retroalimentação que existe entre as duas formas de capital: para o acúmulo de capital social também se faz necessário o acúmulo de informações sobre a favela, mas estas informações precisam se estender para além de índices criminais.

Como se restringem a manter apenas um relacionamento formal com os moradores, que se dá por meio das reuniões ou do acesso ao canteiro social, os agentes do PAC recebem apenas informações específicas a respeito de problemas nas obras ou de demandas referentes às ações do PAC. Assim como no caso da UPP, os agentes do PAC não acessam informações gerais referentes ao convívio na comunidade, aos hábitos dos moradores, ou questões do gênero, que também auxiliam no estabelecimento de vínculos sociais. Um reflexo disso se dá, por exemplo, no tratamento que direcionam aos moradores, que muitas vezes gera irritação: desconhecendo o real nível de instrução dos moradores da favela, o PAC trata-os com uma linguagem mais simples e infantil. Seguindo a lógica da retroalimentação entre capital informacional e capital social, aqui o acúmulo de ambos fica prejudicado.

No caso da UPP Social, o acúmulo de capital informacional é de extrema importância tendo em vista que o programa tem como um de seus propósitos gerar informações que auxiliem as ações dos demais órgãos públicos em favelas. Como pretendem auxiliar órgãos das mais diversas áreas, o escopo de atuação da UPP Social é grande, e precisam levantar e registrar informações dos mais diversos tipos.

Para ter acesso a informações de demandas dos moradores, a UPP Social possui um canal formal de comunicação, o Fale Conosco, e também tem um convívio frequente com os moradores das favelas a quem dão acesso aos seus números de telefone celular. Além disso, em sua etapa inicial, a UPP Social voltou-se para o mapeamento da favela. Os mapas fornecem informações gerais que podem ser úteis aos mais diversos órgãos. 
Tendo a informação como um fim em si mesmo, os agentes da UPP Social parecem conseguir acumular não apenas informações específicas sobre demandas, mas também informações gerais sobre o cotidiano da favela, na qual possuem um convívio frequente com os moradores. As regras informais básicas de convivência que podem gerar conflitos já foram apreendidas pelos agentes da UPP Social, e aqui o capital informacional e o capital social se retroalimentam sem grandes impedimentos.

Os agentes do Territórios da Paz também têm o levantamento de demandas, ou a identificação das temáticas sensíveis às comunidades, como parte do escopo de suas ações. Nesse sentido, o capital informacional aqui também é fundamental para a plena realização do trabalho. A forma como os agentes acessam estas informações se dá, na maior parte das vezes, por meio de conversas informais com moradores, enquanto circulam pela favela.

A destreza dos agentes do Territórios da Paz em lidar com os diversos grupos de conflito da favela também é decorrente do acúmulo de capital informacional a respeito de questões gerais sobre a favela, regras de convivência, linguagem adequada, tudo isso adquirido por meio de seus fortes laços sociais. Assim, aqui também os dois tipos de capital se retroalimentam de forma contínua, propiciando um maior acúmulo de ambos os tipos.

O CRAS, por sua vez, experiencia situação semelhante ao estabelecer relações tão próximas com a comunidade. O relato de uma agente retrata a situação:

"Se acontecer alguma coisa tanto para o bem quanto para o mal, você sabe mesmo sem saber. Sem querer saber, mesmo que você não vá lá, o assunto vem para cá: ou pela própria criança, ou por alguém da comunidade, $\mathrm{o}$ assunto aparece. E às vezes isso de um lado é bom porque você trabalha esse assunto, essa situação conflituosa, ou, enfim, problema, você consegue trabalhar. Mas por outro lado traz essa coisa, essa mistura, né?" (Representante do CRAS 3, Favela da Zona Norte).

As relações domésticas estabelecidas com o CRAS também levam a um compartilhamento de informações, mais uma vez como se os agentes fossem parte da comunidade. Neste aspecto, pode ser positivo, tendo em vista que as informações são úteis para o trabalho de prevenção do CRAS.

A forma como se chegou à categoria teórica do capital informacional a partir dos dados é sintetizada na Figura 2 a seguir:

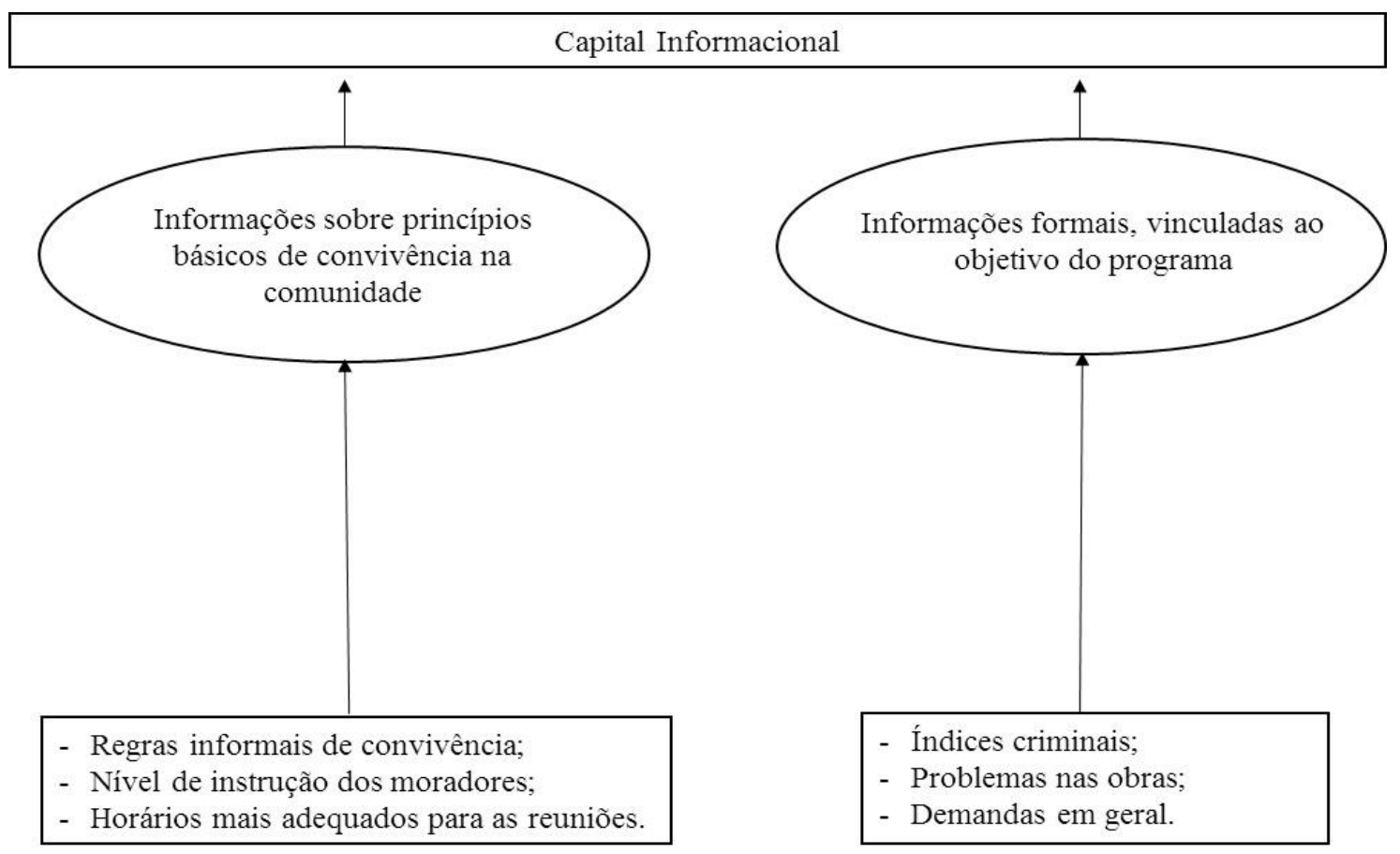

Figura 2. Capital Informacional 
No campo do Estado em análise, o capital informacional se apresenta em duas formas principais: como informações específicas, que dizem respeito ao objetivo do programa ou órgão, e como informações sobre princípios básicos de convivência na favela. De forma geral, pode-se afirmar que aqueles programas que possuem um acúmulo menor de capital social parecem ter acesso apenas ou principalmente ao capital informacional na sua primeira forma, o que, por sua vez, dificulta o acesso ao capital social. Já os programas que possuem um acúmulo maior de capital social, como os casos da UPP Social, Territórios da Paz e CRAS, conseguem ter acesso ao capital informacional nas suas duas formas, e assim capital social e capital informacional parecem se retroalimentar, lembrando a afirmação de Bourdieu (2011) de que as espécies de capital podem ser conversíveis umas nas outras. Esta relação entre as duas formas de capital aqui descritas é ilustrada na Figura 3 a seguir:

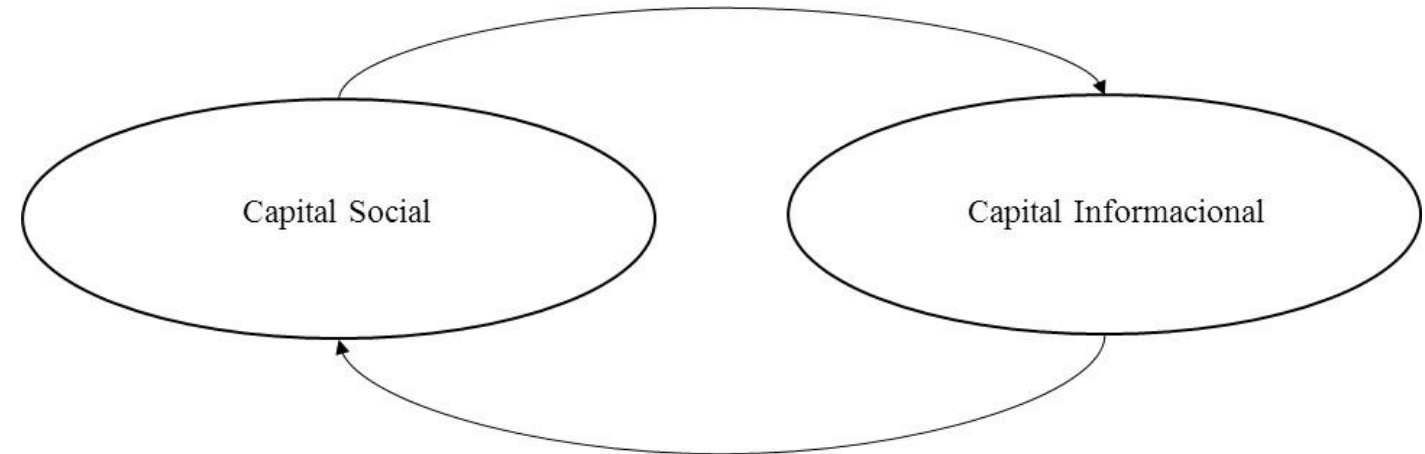

Figura 3. Relação entre Capital Social e Capital Informacional

\section{O capital econômico}

A primeira vez que a primeira autora entrou na UPP da favela da Zona Norte no início de 2013, foi surpreendida diante da incompatibilidade entre as suas expectativas e a realidade do local. Como sempre ouvira falar, especialmente através da mídia, dos grandes investimentos financeiros depositados nas UPPs, imaginava que uma boa infraestrutura era oferecida para o trabalho policial. Entretanto, naquele dia deparou-se com um prédio velho, decorado em seu interior por mesas e cadeiras ainda mais velhas, sujas e sem encosto.

Ao longo da pesquisa, em conversas com os policiais, estes narravam histórias semelhantes às que líamos nos jornais: contavam sobre os grandes investimentos financeiros do governo nas UPPs, que se refletia em um aumento desenfreado do número de policiais formados a cada ano do programa. A explicação para a incoerência que prendia nossa atenção se revelou em conversa com um representante do programa: "Investiu-se muito em quantidade e se esqueceu da qualidade. O projeto é quantitativo. $\mathrm{O}$ secretário se tornou refém de um número: 40 UPPs até 2014" (Representante da UPP 21, Geral).

O investimento era realmente muito grande, mas se diluía entre muitas UPPs. Com o programa, e uma tentativa de mudança nas políticas de segurança pública, os salários policiais foram aumentados e mais ainda no caso de policiais de UPP, que ganhavam, na época da pesquisa, uma gratificação adicional de $\mathrm{R} \$ 750$ oferecida pela prefeitura da cidade do Rio de Janeiro. Os aumentos salariais exigiam um investimento ainda maior diante do aumento de número de policiais formados. Conforme explicou um policial:

"Quando eu entrei na polícia éramos 37 mil homens. Hoje somos 48 mil policiais e com um projeto pra estender até 60 mil homens. Então, por mês, saem do CFAP mil policiais. Por mês! Igual uma fábrica. Porra, de botar inveja em qualquer Ford da vida. Fábrica de polícia". (Representante da UPP 1, Favela da Zona Sul).

Havia, assim, mais um capital importante pelo qual os agentes do campo precisavam lutar para acumular: o capital econômico, retratado por Bourdieu (2004) como uma das formas mais óbvias de capital. O capital econômico, como parece ser evidente, apresenta-se na forma de riqueza material, como dinheiro, ações, bens e patrimônios (Thiry-Cherques, 2006). Entre os agentes do Estado, esta forma de capital é disputada, principalmente, por meio das transferências diretas do governo. 
É quase dispensável comentar o enorme montante de recursos financeiros investidos em um programa de infraestrutura das proporções do PAC - R \$ 52.000.000 é o valor declarado total das obras. A disponibilidade de recursos financeiros do programa é evidenciada pelas proporções das obras realizadas no território, que envolvem aberturas de vias e construções de prédios, e contam com equipamentos pesados: "Usamos todo o maquinário pesado, guindaste, trator, retroescavadeira, bateestaca, monta-carga, guincho, uma porção de coisas, um ferramentário pesado, além da enxada, pá, picareta e estas coisas todas" (Representante do PAC 3, Favela da Zona Sul).

A UPP Social, com seus investimentos iniciais, contratou uma grande equipe de gestores, assistentes e agentes de campo, que foi provida de equipamentos que facilitassem sua circulação em campo: notebooks, máquinas fotográficas, aparelhos celulares. Entretanto, com o contingente de funcionários da UPP Social, não foi possível ter uma equipe exclusiva para cada território. Em geral, cada equipe assume mais de uma favela, de acordo com as suas distribuições geográficas.

No Territórios da Paz trabalhava-se com o básico: cada equipe, composta por um gestor e um assistente, era responsável por um território; cada equipe tinha um laptop e um modem 3G. Os celulares eram escassos, o que também era fonte de reclamações. Os vínculos de trabalho entre os agentes do Territórios da Paz e a Secretaria de Estado de Assistência Social e Direitos Humanos (SEADH) eram precários, assim como os benefícios que recebiam. Além disso, os salários pareciam atrasar com frequência, segundo relatos dos representantes do programa.

Em decorrência das condições ruins de trabalho, muitos agentes foram deixando o programa, e ao longo do tempo alguns territórios ficaram descobertos. Os recursos financeiros disponíveis para os trabalhos em campo eram nulos: "cara, a gente trabalha sem um real" (Representante do Territórios da Paz 1, Favela da Zona Sul).

Os agentes do CRAS parecem possuir os recursos necessários para se manter funcionando. Possuem um prédio dentro das favelas e equipamentos como computadores, impressoras, escâneres, entre outros. De forma geral, os equipamentos funcionam em ambas as comunidades e, mesmo com poucos recursos, conseguem cumprir suas funções.

A forma como os dados empíricos levaram à categoria teórica do capital econômico são retratados na Figura 4 a seguir:

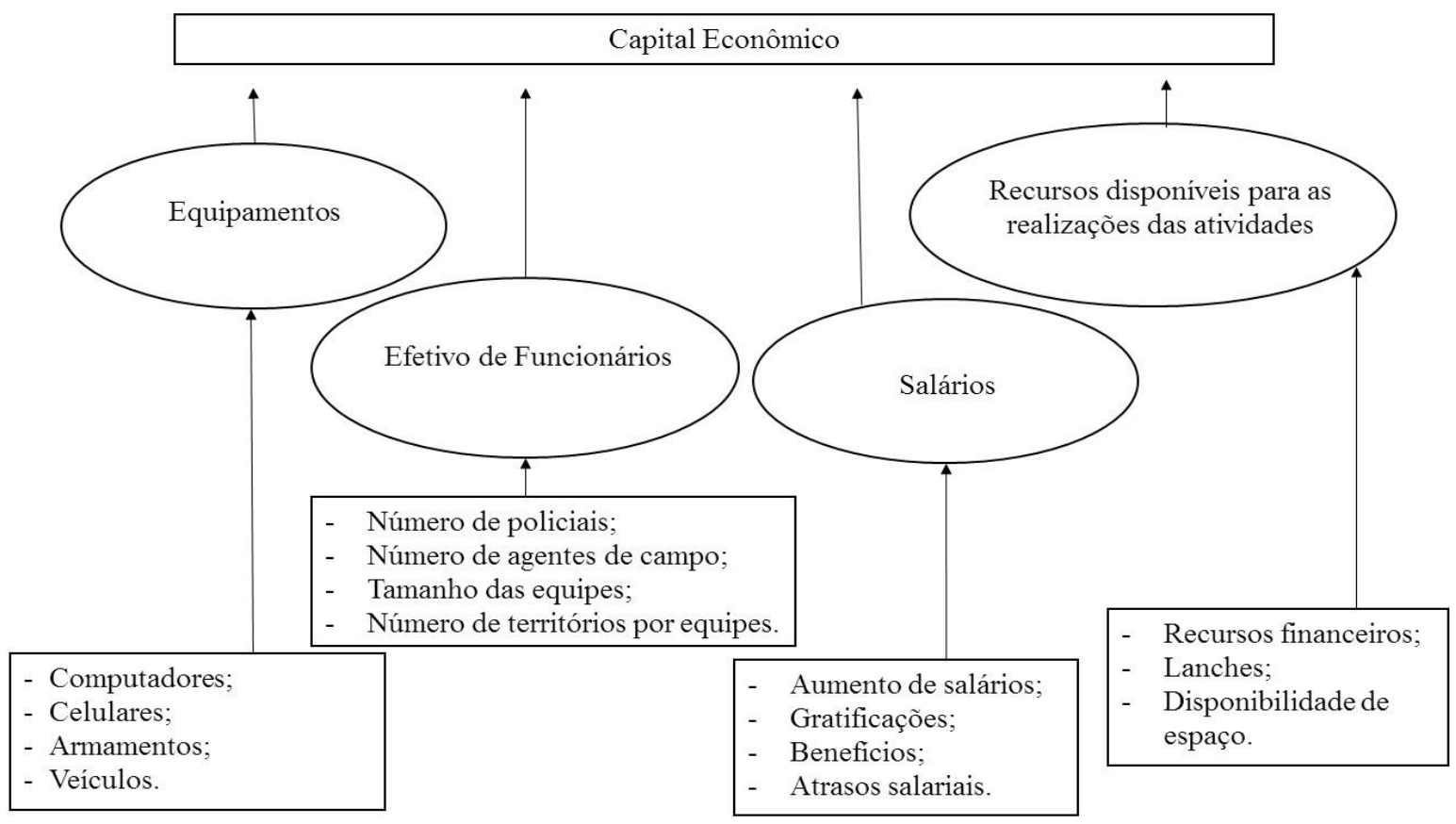

Figura 4. Capital Econômico 
Conforme o exposto, o capital econômico acumulado pelos agentes parece se apresentar em quatro formas principais: nos equipamentos disponíveis, no efetivo de funcionários, nos salários dos funcionários e nos recursos disponíveis para a realização das atividades. Para acumular o capital econômico, os agentes podem conseguir transferências diretas de recursos via governo que, em geral, dependem da sua legitimidade.

\section{Uma nova espécie de capital: o capital espacial}

Em uma terça-feira bem cedo a primeira autora foi à base da Comlurb, em um bairro da Zona Norte, conversar com o gerente responsável pela região que incluía a favela onde vínhamos realizando a pesquisa. Após uma longa conversa em que a autora explicou os seus interesses de pesquisa e fez perguntas a respeito das ações da Comlurb na favela da Zona Norte, o gerente a questionou animado "quer ver com os seus próprios olhos o que é o Estado entrando em uma favela?" (Notas de campo, 8 outubro de 2013). A UPP tinha ocupado no domingo anterior uma nova favela da Zona Norte, e como é habitual nos processos de ocupação, a Comlurb entrara junto para limpar a comunidade, dando-a uma cara nova. O gerente estava se dirigindo para lá, para acompanhar o trabalho dos garis, que por sua vez acompanhavam o Batalhão de Operações Policiais Especiais (BOPE). O convite para visitar uma favela em processo de pacificação pareceu tentador, e também um pouco arriscado. Mas a curiosidade de pesquisadora falou mais alto do que qualquer receio e, bastante eufórica, a primeira autora aceitou o convite.

Entramos em um micro-ônibus da Comlurb e seguimos para o local. Na entrada do morro havia um sofá velho coberto com um toldo, com uma placa que indicava o ponto dos mototáxis. A movimentação parecia fraca naquele dia, e sem nenhum cliente no local, alguns mototaxistas jogavam conversa fora sentados no sofá. Passamos por eles e começamos a subir a principal rua da comunidade até o topo do morro, onde o gerente da Comlurb convidou a primeira autora a descer do ônibus. A favela estava deserta. Nas ruas não se via nenhum morador. Enormes carros do BOPE estavam espalhados pela favela, e os policiais do Batalhão armados com fuzis ficavam parados próximos aos carros. Os garis da Comlurb trabalhavam sem parar em vários pontos da favela, e dirigimo-nos até alguns deles para checar como andava o trabalho. O gerente explicou que a Comlurb sempre acompanha o BOPE nos processos de pacificação. Explicou que suas primeiras ações se voltam para o corte das gramas e a retirada do lixo branco, termo usado pela Comlurb para se referir àquele lixo mais visível, que em geral se apresenta na forma de plásticos ou papéis - ação que tem o rápido efeito de dar uma cara nova à favela. Orgulhoso do trabalho dos garis, o gerente pegou uma câmera fotográfica e começou a registrar a limpeza do local.

Não pudemos deixar de comparar a favela em transição que ali observávamos com as favelas pacificadas com as quais estávamos acostumadas. Percebemos ali uma forte materialização do tráfico no espaço, que embora não mais estivesse presente, especialmente naquele momento de processo de pacificação, havia deixado sua marca por vários cantos da favela. Percebemos que em mesas, bancos e muros espalhados pela favela havia pichação com a sigla do Comando Vermelho (CV) com uma frequência muitíssimo maior do que nas favelas onde realizávamos a nossa pesquisa. $O$ gerente da Comlurb parecia conhecer bem o funcionamento daquela favela antes da entrada do BOPE. Mostrou um local da favela onde o tráfico costumava ficar, por ser o melhor ponto de visibilidade da favela vizinha, dominada por uma facção rival. Este local era na frente da casa de uma senhora, que havia construído um desajeitado muro de concreto protegendo o seu portão, tendo em vista que aquele local recebia tiros constantes da favela dominada pela facção rival. Em frente ao muro de concreto, lia-se um aviso importante: Risco de bala (Notas de campo, 8 outubro de 2013), com assinatura do Comando Vermelho.

Quando retornamos às nossas favelas, depois desta experiência curiosa, começamos a procurar com mais cuidado as marcas do tráfico pelo espaço. Encontramos alguns símbolos do Comando Vermelho, principalmente marcados na calçada e em poucos muros. Bem no topo da favela da Zona Norte, onde antes era o principal local de concentração do tráfico, ainda se lia $\mathbf{C V}$ em um muro bastante visível. Mas o que mais aparecia ali eram as marcas da UPP.

Não é preciso visitar uma favela pacificada para saber que ali existe uma UPP. Circulando pelo Rio de Janeiro, deparamo-nos por acaso com placas que indicam, bem antes de se chegar à favela, a

RAC, Rio de Janeiro, v. 21, n. 4, art. 5, pp. 524-544, Julho/Agosto, 2017, www.anpad.org.br/rac (cc)E 
direção da UPP local. Na entrada da favela, as placas começam a ser acompanhadas da presença dos policiais, devidamente uniformizados e armados, e em geral suas viaturas marcam a entrada da rua principal. É fato que eles estão por toda a parte, e no percurso guiado pelas placas da UPP é possível que se cruze com vários policiais. Quando finalmente se chega ao destino, encontra-se uma sinalização maior, para garantir que se reconheça no prédio, em geral imponente e bem centralizado, a base da UPP. Não dá para ter dúvidas. Assim como não tivemos dúvidas, ao entrar na favela em processo de pacificação, que ali, bem recentemente, era um lugar dominado pelo tráfico.

Como pioneira no processo de ocupação das favelas, a UPP apresenta-se como um rival direto do tráfico, e ambos lutam por dominar um recurso escasso e exclusivo: o espaço da favela. A oposição direta ao tráfico é revelada na fala dos policiais: "A UPP veio mesmo para tirar o território, os traficantes do controle desse território, né?" (Representante da UPP 2, Favela da Zona Sul). Como oposição ao tráfico, quando conseguem o domínio do território, as UPPs tendem a assumir o lugar de seu rival: tornam-se, a seu modo, os novos donos do morro.

Ao ocupar os espaços das favelas, os agentes da UPP facilitam para que outros agentes do Estado façam o mesmo. Com o direito de circular livremente, os mais diversos agentes empenham-se em ocupar o espaço das favelas. Pensam nas estratégias para melhor fazê-lo e entendem que a percepção dos moradores de que os agentes conseguem ocupar as favelas ajuda a legitimá-los.

As UPPs parecem ser bastante eficazes em suas estratégias de ocupação. Além de uma base física, em geral imponente, e contêineres espalhados por outras regiões da favela, o grande efetivo de policiais possibilita que os agentes da UPP se façam presentes pelo território.

O PAC também conta com bases na favela: o Canteiro Social, para a equipe da frente social, que consiste em um apartamento em um dos seus prédios e uma base para a frente de obras. Suas estratégias de ocupação do espaço também se dão por meio das remoções, negociando com os moradores a sua retirada para passagem das obras.

Os programas UPP Social e Territórios optaram, depois de algumas discussões, por não ter bases físicas dentro dos territórios de favela. O dilema era complicado: embora a base física ajude a dar visibilidade ao programa, pode inibir a circulação dos agentes pelo espaço, estratégia que se considera importantíssima para que o programa se faça presente nas favelas. Este dilema aparecia nos discursos dos agentes:

"Eu fico pensando, às vezes, assim, viajando mesmo, nunca elaborei muito isso, mas é porque às vezes era muito difícil para as pessoas entenderem que a gente trabalha bastante pelo fato da gente não ter um espaço físico. Às vezes eu fico pensando se não daria, não daria mais segurança no sentido de dar mais materialidade ao trabalho. Mas ao mesmo tempo, eu acho que a forma da gente trabalhar circulando, eu acho que é vantajosa, assim, por várias coisas, inclusive porque de fato a gente anda muito, nem ia dar para ficar a semana inteira [na favela da Zona Sul], né?” (Representante da UPP Social 4, Favela da Zona Sul).

Os agentes do CRAS começaram a usar como alternativa para a ocupação do espaço o chamado CRAS itinerante: "O CRAS itinerante, de quinze em quinze dias, aí a gente faz esse atendimento em determinados locais na comunidade" (Representante do CRAS 7, Favela da Zona Norte). Assim se faziam presentes em todo o espaço da favela.

Para além de uma preocupação com a ocupação do espaço, os agentes também tentam se fazer visíveis por meio da apresentação de resultados materiais ou de transformações materiais no espaço. A propriedade de visibilidade da matéria faz dela um meio valorizado de se apresentar resultados. E os agentes que não conseguem fazê-lo reconhecem o prejuízo disso para a legitimidade do programa.

No caso das UPPs, isto se torna claro pela redução do objetivo de pacificação ao propósito de esconder as armas e as drogas e, portanto, o tráfico, dentro das favelas. Os policiais reconhecem que o tráfico sempre existirá, em qualquer lugar do mundo e que, portanto, a permanência do tráfico na favela não é um problema, desde que se faça de uma forma discreta. 
Outro elemento material eliminado pelas UPPs, e apresentado como um importante indicativo do sucesso do programa, é o fim dos tiros, que também tem a vantagem de facilitar a circulação pelo território, agora não mais interrompida por inesperados tiroteios. A ausência, ou ao menos a redução, dos tiros na favela pacificada é também sempre apontada pelos moradores como uma mudança bastante positiva trazida pelas UPPs, que torna quase inquestionável a melhoria da vida nas favelas.

Os resultados do PAC não poderiam ser mais materiais e concretos e, portanto, visíveis nos espaços das favelas: o programa realiza obras, abre ruas, levanta prédios. Todos os moradores sabem o que o PAC faz ali e, não obstante os conflitos constantes por conta das remoções, reconhecem que o programa tem um papel ativo.

A UPP Social e o Territórios da Paz enfrentam, mais uma vez aqui, uma dificuldade. Os programas não têm um papel de executores no território, mas apenas de encaminhadores de demandas ou de fortalecedores de redes comunitárias. Diante disso, os próprios agentes reconhecem um problema de visibilidade nas ações dos programas: "É, como nós não somos finalistas, eu não diria que o nosso efeito de trabalho é físico, o que muitas vezes dificulta até a gente explicar o que que é a UPP Social" (Representante da UPP Social 4, Favela da Zona Sul).

O CRAS, embora voltado para a prevenção, vê no Bolsa Família a sua salvação: "a nossa sorte é o Bolsa Família" (Representante do CRAS 3, Favela da Zona Norte). Resultado mais concreto do programa, o Bolsa Família serve para abrir portas para que os moradores acessem outros serviços do CRAS.

É nesse sentido que falamos aqui em um capital espacial como um capital importante no campo do Estado que se analisa. Conforme explicou Bourdieu (2011), para além das espécies de capital fundamentais, em geral presentes em todos os campos, as espécies de capital são definidas de acordo com a lógica específica de cada campo e, portanto, novos tipos de capital podem aparecer em campos distintos. No campo do Estado em ação nas favelas pode-se identificar o capital espacial como uma nova espécie de capital em jogo, que se apresenta em suas duas formas principais: em uma dimensão de territorialidade, que se dá pela ocupação dos agentes do Estado do espaço das favelas, e por uma dimensão de materialidade, que se dá pela apresentação de resultados materiais ou de transformações materiais no espaço. A forma como se chegou ao conceito proposto de capital espacial, a partir dos dados, é ilustrada na Figura 5 a seguir:

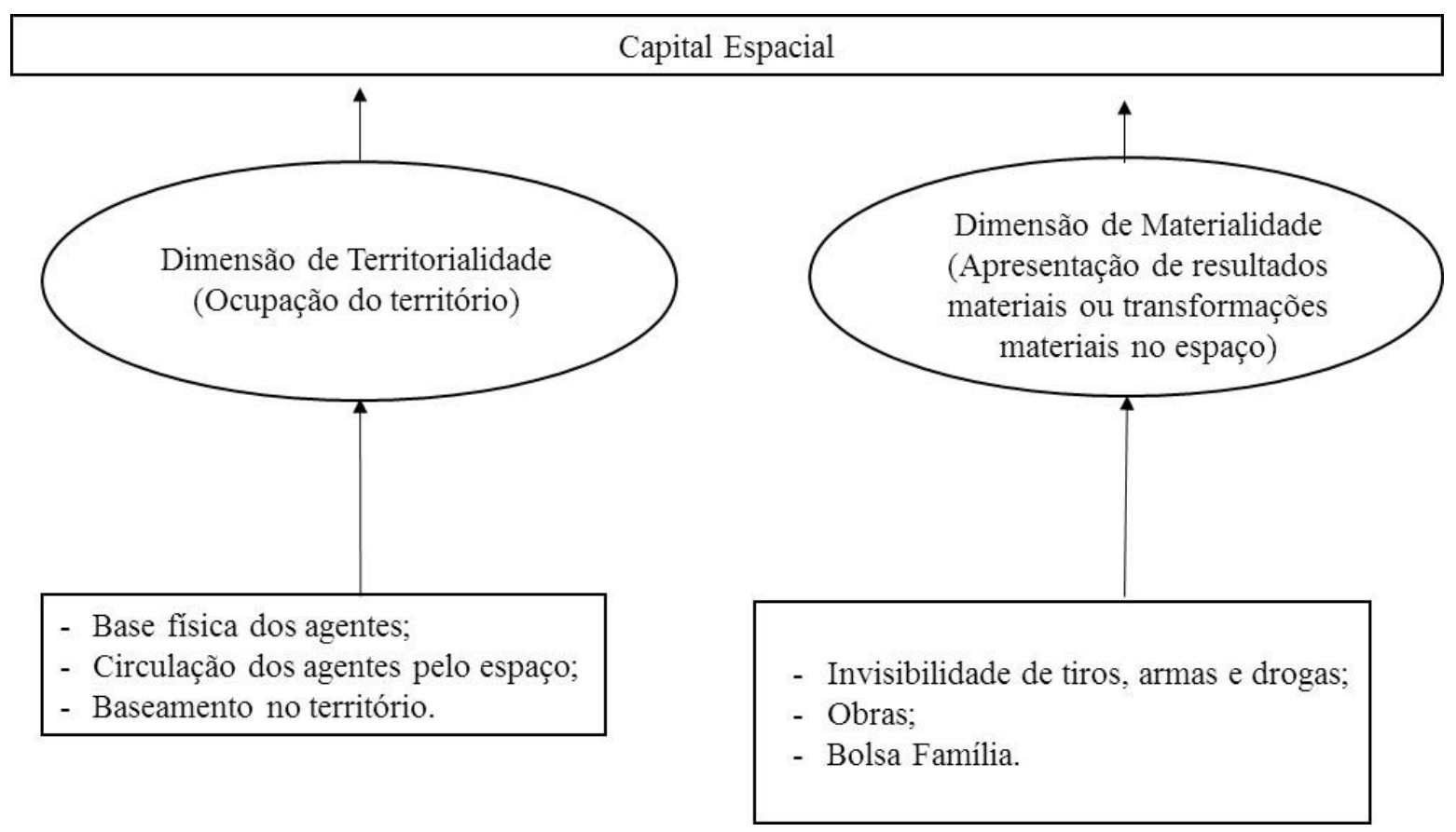

Figura 5. Capital Espacial 
Bourdieu (2014) explica que, por meio da redistribuição de recursos, o Estado produz um efeito simbólico, ou seja, quando seus agentes redistribuem o capital econômico que possuem para a população transformam-no, segundo Bourdieu (2014), em capital simbólico. Para Bourdieu (2014), a redistribuição produz legitimidade. Segundo o autor, este processo se apresenta como algo ambíguo, pois é um processo em que o capital vai ao capital: "Até a redistribuição é uma das formas por excelência de acumulação, pela transmutação do capital econômico em capital simbólico" (Bourdieu, 2014, p. 361). É por meio do capital econômico que o Estado consegue acumular o capital simbólico que, segundo Bourdieu (2014), se apresenta também na forma de um acúmulo de legitimidade.

Indo ao encontro de Bourdieu (2014), o que aqui se pretende mostrar é que quando o processo de redistribuição se dá por meio de um acúmulo intermediário do capital espacial, aumenta-se o potencial de transformação de capital econômico em capital simbólico. No campo do Estado aqui analisado, os agentes capazes de transformar o seu capital econômico em capital espacial foram aqueles que também apresentaram maior acúmulo de capital simbólico, observado pela legitimidade que estes agentes possuíam perante a população.

Não obstante o baixo volume de capital social acumulado pela UPP, o reconhecimento deste agente diante dos moradores era inquestionável. Os policiais atribuíam a aparente legitimidade do programa à sua presença física no território e às inegáveis transformações materiais que este trouxe para a favela:

"Quem tem estrutura física dentro do território é a UPP, que está aqui pintada de azul e branco e todo mundo tem como referência. Quem está fardado na rua com a bandeira do Estado no ombro? É o policial, então ele acaba sendo referência". (Representante da UPP 3, Favela da Zona Sul).

Como consequência de sua legitimidade, as UPPs começaram a ser reconhecidas como o Estado na favela, e os moradores adquiriram o hábito de demandar dela as mais diversas funções, mesmo aquelas que eram claramente atribuições de outros agentes do Estado.

Os agentes do PAC, como visto anteriormente, também não conseguiram um grande acúmulo do capital social; entretanto, o programa era reconhecido mesmo por aqueles que brigavam nas reuniões: "O PAC em si ele veio, fez uma melhora. Fez ou não fez? Fez uma melhora, né? Como eu falei, estou sentado em cima do antigo trilho que levava o bondinho para cima do morro ... esses olhos aqui viram, não foi ninguém que contou, eu estava aqui. É, eu vi. Está mudando" (Morador 9, Favela da Zona Sul).

UPP Social e Territórios da Paz, não obstante sua relação de proximidade e amizade com os moradores das favelas, já não tinham o mesmo reconhecimento. Os moradores eram unânimes em afirmar que não conseguiam enxergar o que os dois programas traziam para eles: "a UPP Social, há muito tempo se fala de levantamento de dados, que ela tá dando encaminhamento, isso e aquilo, mas eu não vi nada de concreto" (Morador 10, Favela da Zona Sul). E o mesmo se afirmava do programa Territórios da Paz: "Eu vejo a [Valéria] também, um pouquinho, como a UPP Social.... A UPP Social é município e a [Valéria] é do Estado. Mas, não vejo grandes acontecimentos não" (Morador 10, Favela da Zona Sul).

O CRAS, por sua vez, tinha grande parte do seu reconhecimento decorrente do Bolsa Família: "Até na divulgação do CRAS, reconhecimento das coisas, porque assim, quase ninguém sabe o que é o CRAS, né? A pessoa sabe assim, onde faz o Bolsa Família" (Representante do CRAS 8, Favela da Zona Norte). Mas para os moradores este agente se resumia a um provedor do Bolsa Família dentro da favela.

Aqui também, no que diz respeito às relações entre as espécies de capital, a conversão do capital econômico em capital simbólico, por meio do acúmulo de capital espacial, parece se dar de uma forma cíclica. $\mathrm{O}$ fechamento do ciclo se dá na medida em que a legitimidade dos programas também leva ao acúmulo do capital econômico, tendo em vista que programas com maior legitimidade recebem mais recursos públicos. É em parte porque obra traz reconhecimento e porque as UPPs se tornaram o grande representante do Estado nas favelas, que são estes os programas que recebem mais investimentos. A relação cíclica entre as espécies de capital é ilustrada na Figura 6 a seguir: 


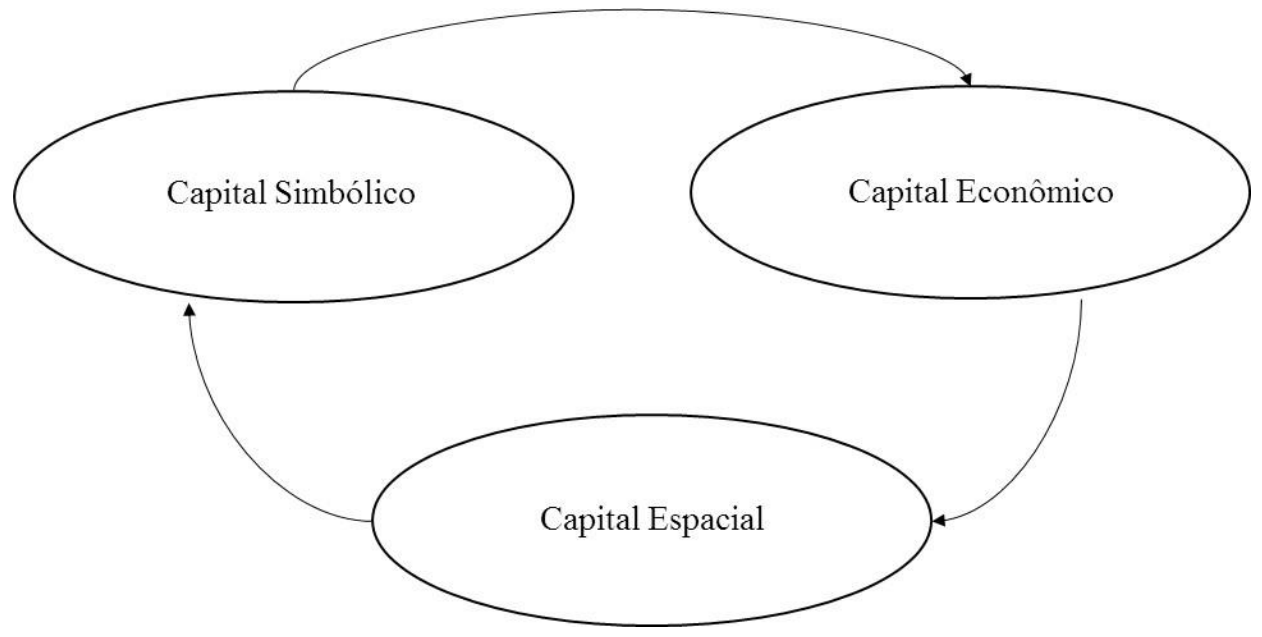

Figura 6. Relação entre Capital Econômico, Capital Espacial e Capital Simbólico

Portanto, o que se observou foi que os programas com maior concentração de capital econômico têm mais facilidade para redistribui-lo por meio do acúmulo do capital espacial. Quando esta é a via de redistribuição privilegiada, amplia-se o potencial de transformação do capital econômico em capital simbólico, o que corresponde a uma maior legitimidade dos agentes. Por sua vez, a legitimidade serve como um atrativo para maiores investimentos financeiros, contribuindo para um maior acúmulo de capital econômico.

\section{Conclusão: Marcando Posições}

Neste trabalho, propusemo-nos a analisar como se dá a disputa por capitais pelos agentes do campo burocrático do Estado em ação nas favelas, no contexto da pacificação. A partir da análise empírica foi possível concluir que a UPP, como o agente do campo que apresenta maior legitimidade, de acordo com o descrito, apresenta-se também como o agente que mais diretamente ameaça o poder do tráfico. Como forma de confrontá-la, o tráfico apela para a principal via sobre a qual ainda tem algum controle e tenta restringir o seu acesso ao capital social, por meio de ameaças e retaliações a moradores que, de alguma forma, estabeleçam contato com a polícia. Entretanto, conforme mostrado, embora o capital social seja importante para dar acesso ao capital informacional, o seu baixo volume não restringe o acesso ao capital espacial, que lhe dá legitimidade, tendo em vista que este compõe um outro ciclo de capitais - aquele no qual capital econômico, capital espacial e capital simbólico são convertidos nesta ordem.

A partir das análises de distribuição de capitais, é possível posicionar os agentes do campo em um continuum que tem como extremos as posições de incumbentes e desafiadores. Os incumbentes, conforme Fligstein e McAdam (2012), ocupam as posições dominantes no campo, e os desafiadores, em posições inferiores, aguardam oportunidades para tentar reverter a ordem do campo. Embora se reconheça que as estruturas do campo são extremamente mais complexas do que a simples dicotomia incumbentes/desafiadores, o posicionamento dos agentes neste continuum, de acordo com o volume de capital que possuem, já nos antecipa muito sobre esta estrutura e nos indica uma das suas características mais importantes: quem são aqueles que dominam neste campo. O posicionamento dos agentes pode ser observado na Figura 7 a seguir: 


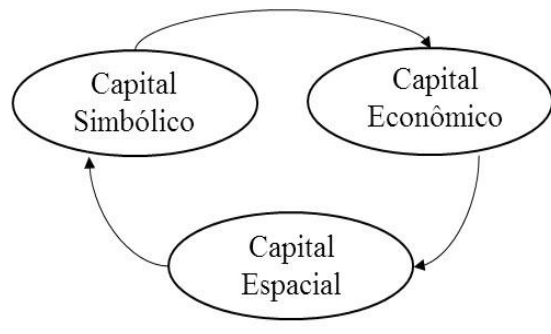

Incumbentes

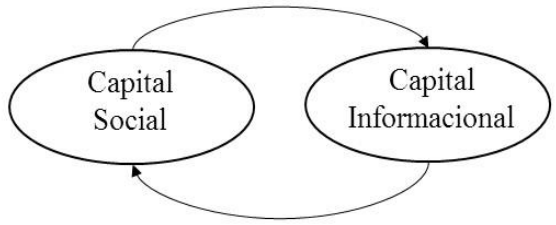

Desafiadores

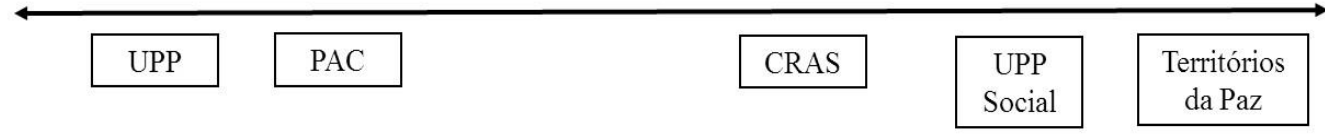

Figura 7. Posição dos Agentes no Campo

Conforme mostra a figura, CRAS, UPP Social e Territórios da Paz, com um maior acúmulo de capital social e informacional, mantêm-se como desafiadores no campo. Já UPP e PAC, com maior acesso aos capitais econômico, espacial e, consequentemente, simbólico, assumem a posição de incumbentes.

$\mathrm{Na}$ fala dos agentes a respeito de programas que sucederam a entrada das UPPs, como a UPP Social e o Territórios da Paz, está presente o reconhecimento da necessidade de se apresentar como um contraponto à figura do capitão, alguém que tivesse recursos de poder e conseguisse projetar uma ascendência similar à do capitão dentro do espaço das favelas. No entanto, com base na análise que apresentamos aqui, tais programas não têm sido bem-sucedidos em conseguir se apresentar como uma oposição legítima à UPP porque não conseguem concentrar as espécies de capital capazes de serem convertidas em capital simbólico.

As disputas por capitais entre agentes do campo burocrático do Estado em ação nas favelas apontam para uma nova espécie de capital, o capital espacial, e para o estabelecimento de elaboradas relações entre as diferentes espécies de capital. A bem fundamentada proposta de Bourdieu para se pensar o Estado, quando transposta para o contexto atual das favelas, demandou aqui ser complementada por uma nova espécie de capital, que amplia as possibilidades de compreensão deste campo. O conceito de capital espacial aqui proposto também aponta para uma intensa interferência do Estado na materialidade das favelas, como forma de acúmulo desta espécie de capital.

Propomos, nesse sentido, que estudos de poder na área de estudos organizacionais passem a levar em conta esta nova espécie de capital aqui apontada e investiguem a relevância do capital espacial em outros contextos ou em outros campos de poder. De forma mais específica, propomos uma agenda de pesquisa em torno do conceito de capital espacial, para que as principais lacunas em torno do novo conceito possam ser preenchidas. Sugerimos, assim, que pesquisas futuras busquem investigar de que forma o valor do capital espacial se altera de acordo com a visibilidade de um dado território. Será que territórios que não aparecem constantemente na mídia como as favelas pacificadas são menos valorizados em termos de capital espacial? Outro aspecto em torno do conceito que merece ser levado adiante diz respeito à relação entre o valor do capital espacial e as transformações materiais no espaço. Será que quanto mais valorizado for o capital espacial mais intensas serão as transformações na materialidade do espaço, como forma de acumulá-lo? Em nossa pesquisa, concluímos que esta relação está presente. Mas ainda cabe investigar se podemos extrapolá-la para outros contextos e outros campos de poder. Nestes casos, faz-se importante, em termos metodológicos, a comparação entre territórios diferentes, o que faz da pesquisa empírica um grande desafio ao pesquisador. Ainda, cabe investigar que outras espécies de capital podem ser convertidas em capital espacial. Apontamos, na presente pesquisa, a conversão entre capital econômico e capital espacial, o que traz consequências importantes para se pensar a legitimidade de agentes do Estado neste contexto. Será que em contextos diferentes as espécies de capital se relacionam de maneiras alternativas? Por fim, em que campos de poder tal espécie de capital se destaca como relevante ou, até mesmo, como o capital simbólico do campo? Tais questões 
abrem espaço para diversas possibilidades de pesquisa e nos ajudam a ressaltar que as contribuições de nosso trabalho não se esgotam aqui.

\section{Notas}

\footnotetext{
${ }^{1}$ A expressão pacificação refere-se à instalação de uma Unidade de Polícia Pacificadora, Unidade de polícia vinculada à Polícia Militar do Rio de Janeiro, no interior da favela, como forma de retomar o território do poder do tráfico de drogas.

${ }^{2} \mathrm{O}$ PAC é um programa vinculado ao governo federal, voltado para obras de infraestrutura.

${ }^{3}$ A UPP Social é um programa municipal, vinculado ao Instituto Pereira Passos, que busca fazer uma articulação entre os moradores de favelas e o poder público.

${ }^{4}$ O Territórios da Paz é um programa vinculado à Secretaria Estadual de Assistência Social e Direitos Humanos, voltado para o fortalecimento de redes nas favelas.

${ }^{5}$ O CRAS é vinculado à Secretaria Municipal de Desenvolvimento Social e visa garantir o acesso dos cidadãos aos seus direitos.
}

\section{Referências}

Bourdieu, P. (1996). Razões práticas: sobre a teoria da ação. Campinas, SP: Papirus.

Bourdieu, P. (2004). Coisas ditas. São Paulo: Brasiliense.

Bourdieu, P. (2011). A distinção: crítica social do julgamento (2a ed.). Porto Alegre, RS: Zouk.

Bourdieu, P. (2012). Sur l'État: cours au college de France. Paris: Raisons dàgir/Éditions du Seuil, janvier.

Bourdieu, P. (2014). Sobre o Estado. Cursos no Collège de France. São Paulo: Companhia das Letras.

Bourdieu, P., \& Wacquant, L. (2012). Una invitación a la sociologia reflexiva. Buenos Aires: Siglo Veintiuno Editores.

Bourdieu, P., Wacquant, L., \& Farage, S. (1994). Rethinking the State: genesis and structure of the bureaucratic field. Sociological Theory, 12(1), 1-18. http://dx.doi.org/10.2307/202032

Emirbayer, M., \& Johnson, V. (2008). Bourdieu and organizational analysis. Theory and Society, 37(1), 1-44. http://dx.doi.org/10.1007/s11186-007-9052-y

Everett, J. (2002). Organizational research and the praxeology of Pierre Bourdieu. Organizational Research Methods, 5(1), 56-80. http://dx.doi.org/10.1177/1094428102005001005

Fligstein, N., \& McAdam, D. (2012). A theory of fields. New York: Oxford University Press.

Misoczky, M. C. (2006). Leituras enamoradas de Marx, Bourdieu e Deleuze: indicações para o primado das relações nos estudos organizacionais. In M. M. F. Vieira \& D. M. Zouain (Orgs.), Pesquisa qualitativa em administração (pp. 71-96). Rio de Janeiro: FGV.

Sallaz, J. J., \& Zavisca, J. (2007). Bourdieu in American Sociology, 1980-2004. Annual Review of Sociology, 33, 21-41. http://dx.doi.org/10.1146/annurev.soc.33.040406.131627

Thiry-Cherques, H. (2006). Pierre Bourdieu: a teoria na prática. Revista de Administração Pública, 40(1), 27-55. http://dx.doi.org/10.1590/S0034-76122006000100003 


\section{Dados dos Autores}

\section{Vanessa Brulon}

Av. Pasteur, 250, 22290-240, Rio de Janeiro, RJ, Brasil. E-mail: vanessabrulon@facc.ufrj.br

Alketa Peci

Praia de Botafogo, 190, 22250-900, Rio de Janeiro, RJ, Brasil. E-mail: alketa.peci@fgv.br 